\title{
The Young Generation of Catholics in the Face of Ecological Problems Exemplified by the Initiatives of the Catholic Youth Association
}

\author{
Andrzej Lubowicki \\ Catholic Youth Association \\ Miodowa 17/19, 00-246 Warsaw, Poland \\ a.lubowicki@ksm.org.pl• ORCID 0000-0002-5535-4338
}

\section{Summary}

The Catholic Youth Association (Pol. KSM) operates within 41 dioceses of the Roman Catholic Church in Poland and according to data from 2019, has approx. 20,000 members in almost 1,000 parish units and community circles. Numerous initiatives undertaken by KSM include, among others, activities aimed at protecting creation. This study presents several of the most important ecological projects implemented by KSM: 1. Bug, the River of Life - Education for Youth, Youth for Sustainable Development; 2. Youth of this Earth; 3. Electro Responsible; 4. Kayaking Patrol of St. Francis; 5. Youth for the Environment; 6. Youth Environment.

\section{Keywords}

Catholic Youth Association, Christianity, ecology

The modern world is an arena for local armed conflicts, disputes and wars over borders and the right to land. Today's world, moreover, provides a forum for various manifestations of social injustice. "Our" world can also be compared to a stage on which an ecological drama is presented its theme being a lack of due respect for nature, chaotic exploitation of natural resources and gradual deterioration of the quality of life. This situation is well reflected in the words of John Paul II: "in addition to the irrational destruction of the natural environment, we must also mention the more serious destruction of the human environment, something which is by no means receiving the attention it deserves. Although people are rightly worried - though much less than they should be - about preserving the natural habitats of the various animal species threatened with extinction, because they realize that each of these species makes its particular contribution to the balance of nature in general, too little effort is made to safeguard the moral conditions for an authentic 'human ecology'. Not only has God given the earth to man, who must use it with respect for the original good purpose for which it was given to him, but man, too, is God's gift to man. He must therefore respect the natural and moral structure with which he has been endowed. In this context, mention should be made of the serious problems of modern urbanization, 
of the need for urban planning which is concerned with how people are to live, and of the attention which should be given to a 'social ecology' of work" (John Paul II 1991: No. 38 ).

The authors of the scenario, scenographers, directors and actors of this drama are people who cherish a desire to live a happy life. People, who at the same time live a life permeated with a sense of temporariness and insecurity about tomorrow leading to multiple manifestations of collective selfishness, the desire to possess and to use violence (John Paul II 1989: No. 1).

The problems of environmental degradation are dealt with by ecological sciences, which include various disciplines: ecology, sozology, sozotechnics, sozoeconomics, sozopsychology, environmental ethics, bioethics, ecophilosophy, ecological legislation, ecoteology, ecological policy, ecological psychology, ecomedicine (Dołęga 2002a). All these sciences serve to build ecological social awareness. John Paul II in his Message Peace With God the Creator, Peace With All of Creation, emphasizes that "faced with the widespread destruction of the environment, people everywhere are coming to understand that we cannot continue to use the goods of the earth as we have in the past. The public in general as well as political leaders are concerned about this problem, and experts from a wide range of disciplines are studying its causes. Moreover, a new ecological awareness is beginning to emerge which, rather than being downplayed, ought to be encouraged to develop into concrete programmes and initiatives." (John Paul II 1989: No. 1). The concept of practicing ecological sciences is based on general assumptions which, according to J. Dołęga, can be formulated as follows: "nature, the cosmos, the entire natural environment that surrounds us are recognized as the work of the Creator; - man in whom different developmental lines of the universe converge constitutes a specific centre in the natural environment; - good and beauty are perceived in nature and man - the values that determine the development of his personality; - life in general and human life and health are recognized as the highest values; - ethics, morality and ecological legislation are important elements of ecological education; - human psychophysical unity; - the basic layers of human structure (biological, mental and spiritual); human immanence and transcendence towards nature" (Dołęga 2002b: 236-237).

The above-presented assumptions of ecological sciences clearly show that the interdependence of many ecological challenges requires a coordinated search for a solution based on a morally coherent vision of the world. For Christians, this vision is founded on religious beliefs derived from the truth of Revelation. It is only in this perspective that the ecological aspects of the Christian vocation can be fully reflected.

In the modern world, any initiatives shaping the Church members into mature Christians and leading to their active participation in the community and mission of the Church are highly valuable and necessary. The Catholic Youth Association can undoubtedly be included among organizations undertaking such initiatives nationwide. Being a Church legal entity, this association gathers in its structures young lay Catholics who conduct various apostolic formative activities within the Church and beyond it. In the present situation, the Catholic Youth Association performs a formative mission and works towards engaging the younger generation in the mission of the Church, helping them to discover their calling (Lubowicki 2014: 13).

After the Second Vatican Council, lay people were given a mandate allowing them to seek their own mission in the Church. This way, the apostolate organized by the laity gained on official and public importance and was appointed a proper place of the lay apostolate (Passicos 1992: 78-79). The Catholic Youth Associationan association of young Catholics - is an organization related to the Church hierarchy. This relationship has, on the one hand, a 
caring form as regards the hierarchy, and on the other, a complementary and expanding character as regards the role of KSM. The laity have their share in the mission of the Church and in this way they complement and expand this mission-it is a special discovery of the Second Vatican Council. This relationship means that KSM as an association of young Catholics is inscribed in the official mission of the Church, and consequently, it should also discover and define its own mission. This mission, due to the fact that KSM gathers young people and addresses all its activities first and foremost to the young, appears in a particular manner as having a formative character. Young people need to be moulded and educated.

KSM's main and fundamental task is that of "shaping mature Christians and taking active part in the community and mission of the Church by spreading and disseminating Catholic values and principles in all areas of life, especially in the social and cultural spheres of life" (Statute of the Catholic Youth Association 1993: \$13). This difficult, at the same time large-scale, mission has already had a precedence in the past. The Association's roots go back to the interwar period when, after years of partitions, it began its activities as the Catholic Association of Male Youth and the Catholic Association of Female Youth within the structures of the Catholic Action. The organization participated then in the religious, moral, economic and social reconstruction of Poland. The Association's formative activities have been widely presented from the historical perspective in numerous studies. It was due to this activity that, for example, during World War II many KSM soldiers did not hesitate to take part in the defence of Poland. Another significant result of the Association's activity was the country's economic and social development based on the involvement of young people (Lubowicki 2014: 13).

The guiding principle of the Catholic Youth Association, reactivated at the request of John Paul II, is participation in the realization of the Church's mission. The formative program adopted by the organisation is based on the Catholic Social Teaching in which man takes a central position, since it is man who in a relationship to God and creatures is to "subdue the earth" and shape the environment.

As a popular sayings goes "What youth is used to, age remembers...". There is a lot of truth in these words, because if we fail to take care of ecological education or of shaping pro-environmental behaviour in young people, then in a couple of years, if not earlier, we may live in a world full of garbage, in a heavily polluted and degraded environment. The Catholic Youth Association fully recognizes the crucial role of ecological education in the proper upbringing of children and youth as well as in shaping their ecological awareness, which is why, over the years of its activity it has been involved in carrying out numerous ecological projects. The Association members are deeply convinced of the need to implement ecological projects being aware that widespread extracurricular education and upbringing towards sustainable development of both children, youth and adults is the key segment of activities aimed at ecological education. The Catholic Youth Association, as a nationwide organization gathering approximately 15,000 young members, regards training active youth in the area of broadly understood ecology and environmental protection as one of its most important tasks. This need arises from specified problems presented in the public debate or issuing from the necessity to shape the younger generation. Projects implemented by the Catholic Youth Association of the Drohiczyn Diocese had nationwide coverage. They were carried out in cooperation with diocesan associations from all over Poland. The completed projects comprised a series of various activities properly planned, described, carried out and, finally, evaluated. All projects had an educational character and they were conducted with particular involvement 
of young people. The completed projects include:

1. Bug, the River of Life - Education for Youth, Youth for Sustainable Development (orig. Bug rzeka życia edukacja dla młodzieży, młodzież dla ekorozwoju) - is the first ecological project implemented by KSM with the support of the National Fund for Environmental Protection and Water Management, carried out by the Catholic Youth Association of the Drohiczyn Diocese in cooperation with diocesan associations in Poland (Project: Bug rzeka życia... 20072009). The project was aimed at raising the level of knowledge from the area of ecology through conducted trainings, by activating young people, initiating the activities of regional ecological centres in the course of implemented specific initiatives, by promoting the idea of the ecology of the spirit and the Catholic social science on ecology. The project involved a series of ecological training for young people aged 18-30, particularly addressed to those who associate their further professional development with environmental protection. The training program covered topics in the field of environmental management, education, organic farming and ecotourism. The educational activities were planned in such a way as to allow for passing from theory, through workshops, to the implementation of participants' own projects in practice. Over 600 people took part in the trainings which were divided into four stages. The first stage involved national trainings conducted for the purpose of selecting group leaders and it was followed by regional trainings for leaders selected in the preceding stage. A group of leaders formed after those two stages was subsequently prepared to manage and implement regional environmental initiatives.
The next stage involved field activities organized during a 5-day kayaking tour for 48 participants along the Bug River on the Serpelice-Zuzela section, and a nationwide bicycle rally along the eastern border of the country from Ustrzyki Dolne to Wiżajny. The 50 participants of the rally covered $900 \mathrm{~km}$ in 10 days, learning the principles of sustainable development. The last stage involved a specialized training comprising 4 seminars: environmental management, ecology and ecological education, organic farming, ecotourism. Those specialist trainings were aimed at, among others, practical preparation of participants to implement projects developed during classes. As part of the project, young people were able to create from scratch Regional Centres of Environmental Initiatives within partnership cooperation and with the involvement of local organizations and the support of regional and local authorities. Young people gained knowledge from the area of project management, conducting business activity, activities undertaken to revive the ecology of the spirit and the care for the sustainable development of our country.

2. Youth of this Earth (orig. Młodzi Tej Ziemi) is he second ecological education project, implemented within the National Ecological Strategy of 2001 (Project: Młodzi Tej Ziemi 2009-2010). The project was addressed to primary school children, junior high and high school students, university students and working youth up to 25 years of age. Financed with a subsidy from the National Fund for Environmental Protection and Water Management under the competition procedure. The project was aimed at the development and active implementation of an ecological education program by a group of young nature ambassadors created for that purpose. 
An important aspect of the project was its impact on raising the level of ecological awareness among children and youth. The project covered the following events: Environmental Education Educators' Workshops (6o participants) and Coaching Trainings (10o participants), 3 editions of Field Workshops on rivers (14.4 participants), Field Workshops on Environmental Education (880 participants), national photography competition, Regional Ecological Festival in Drohiczyn as part of the Youth of this Earth Day (1153 participants). The educators' and coaching workshops were aimed at expanding the knowledge of young people based on the Natura 2000 program and at selecting leaders of local environments who prepared lesson plans for classes on ecology and environmental protection which were later used during the Field Workshops on Environmental Education. Poland gained new educators and trainers of ecological education. The "Youth of this Earth" project also included active ecological education in the field of water management and flood protection in Natura 2000 areas. It was due to the fact that at that time Poland was struggling with heavy floods affecting the whole country. The goal of the water workshop conducted during kayaking trips on the Bug and Rospuda Valley was active education based on promoting the tourist and natural assets of these areas and examination of water purity. The Ecological Festival in Drohiczyn, in turn, was planned to present Podlasie as an area abounding in flora and fauna, raising the society's awareness, especially that of young people, of the need for ecological education so that the next generations could enjoy the beauty of nature. Another goal was to shape the awareness of the necessity to build partnership for sustainable development. As part of the "Youth of this Earth" project, a social networking site www.mlodzitejziemi.pl was set up and it soon reached over 2 million page views. The site was meant to serve as a tool of communication for groups, movements and associations, communities and organizations gathering young people who are aligning themselves with Catholic values. The site helped integrate the youth environment. Following the teaching of the Second Vatican Council, young lay people became engaged in apostolic activity. The portal was a response to various types of social networking sites promoting rather questionable values. It facilitated communication within and between groups and communities, which is of great importance in social interaction. The site brought together several thousand young people from all over Poland. The project completion was summed up by releasing a $C D$ with materials covering ideas and solutions worked out during its implementation, including programs of activities that might prove useful for the organization of camps and workshops on ecological topics as well as lesson plans and presentations for ecological education classes. The prepared CD can be used during workshops for young people, religion lessons, nature and biology lessons or during general education classes.

3. Electro Responsible (orig. Elektro Odpowiedzialni). Protection of the natural environment against the consequences of improper disposal of electro-waste, its recovery and recycling is one of the elements of ecological education. The "Electro Responsible" project was carried out in the scope of the WEEE, i.e. the Waste Electrical and Electronic Equipment, and it was addressed to the inhabitants of eastern Poland, the so-called Poland B, a less industrialized part of 
the country, neglected due to cultural, geographical, social and economic reasons. The project implemented as part of a competition from the subsidy of the National Fund for Environmental Protection and Water Management, was a response to the issue of general lack of knowledge as regards the definition and handling of electro-waste and the disastrous impact of electro-waste on the natural environment (Project: Elektro Odpowiedzialni 2009-2010). The project was planned to meet the demand for extracurricular education for children and youth and the use of modern media. Its goal was mainly manifested in the promotion of attitudes of pro-environmental involvement and behaviour among preschool children, school youth, as well as adults, local government officials and businessmen who have an impact on the young generation in local communities. The project comprised educational workshops in kindergartens - 80 workshops (4203 participants), educational workshops in schools - 8o workshops (2068 participants), 4 editions of competitions, educational events entitled ELECTRO EVENTS (10 events devoted to educational games and electro-waste collections with the participation of the ELECTRO PATROL demonstration group, as well as project mascots in the shape of a washing machine, TV set and battery). Several dozen tons of electrical and electronic equipment waste were collected during the events. One of the awards in the competition was participation in the Field Workshops on Environmental Education, during which young people underwent a training in creative thinking in the field of ecology. The workshops provided training for 149 participants and their outcome were educational spots created by young people. Participants of workshops and competitions had a chance to expand their knowledge in the field of electronic waste, learning about the ways of their safe disposal. The modern world is full of electrical and electronic equipment and young people use it on a daily basis, so the knowledge regarding its proper handling is very important. Young people should be involved in active environmental protection and shown how to promote pro-environmental attitudes. Those are the main issues that children and young people were taught by the "Electro Responsible" project in 2012-2015. As part of the project, electro-waste collection took place.

4. Kayaking Patrol of St. Francis (orig. Kajakowy Patrol św. Franciszka) - is another project implemented by the Catholic Youth Association, co-financed by the National Fund for Environmental Protection and Water Management in Warsaw as part of the competition. The project had two editions (Project: Kajakowy Patrol św. Franciszka 2009-2013). Both of them revolved around the issues of ecological education in the field of water protection and water management, the species inhabiting water reservoirs, promotion of pro-environmental attitudes among schoolchildren, the population living near rivers, tourists, fishermen and indirect recipients of the project. The project was also aimed at raising the level of ecological awareness, especially of children and young people from the areas where environmental quality standards are exceeded, and those which suffered from natural disasters. Project activities were directed to: students of primary, junior high and high schools as well as universities; tourists, fishermen, companies and organizations dealing with water tourism, as well as to the inhabitants of the areas near rivers and water reservoirs. Both 
project editions covered Water Workshops on Environmental Education in the form of kayaking trips; Local River Cleaning Actions; educational workshops in kindergartens and primary schools; educational events in various cities throughout Poland; demonstration campaigns (during which the Demonstration Group in special costumes, swimming in branded kayaks and equipment travelled all over Poland to propagate the activities of the Kayaking Patrol and show the gravity of the problem of river pollution in our environment); happening campaigns, among others under the slogan "Hitch-hiking a kayak", "Kayaking in Krupówki", "Kayaking from the slope", ecological competitions (art, photography and theatre), press conferences, photo exhibitions, Water Theater Tournée. The initiative to educate the community emerged when KSM organized the Drohiczyn Diocese of kayaking on the rivers of Eastern Mazovia. During the excursions along the kayaking trails the participants could find large amounts of garbage left in the water and on the shore, e.g. tires, pieces of household appliances, animal carcasses, plastic, jars, cans and other types of garbage. During the two editions, Several dozen tons of garbage were picked up from rivers. Water protection has been an important ecological issue for many years. Our society seems to be rather insensitive to the problem of water pollution, most of us fail to realize the basic concepts of water protection. That is why, the "Kayaking Patrol of St. Francis" project, and especially the project mascot, Fish Lucius, tried to sensitize both young people and adults to the problem of water pollution, teach them a habit of observing changes in the surrounding environment, show the benefits of waste segregation and saving water. Fish Lucius propagated the slogan: "I don't swim in trash." Most people do not see the relationship between human activities and changes in the surrounding environment. We also fail to realize the fact that excessive waste production threatens our environment. The Kayaking Patrol of St. Francis tried to point it out to the inhabitants of the whole country. As regards numbers, the Kayaking Patrol of St. Francis I included: 50 workshops in schools 1186 participants; 38 show events; Water Workshops on Environmental Education - 6oo participants; 4 conferences; 5 exhibitions; 12 events; 3 competitions; the Kayaking Patrol of St. Francis II included: 50 workshops in schools - 1186 participants; 38 show events; Water Workshops on Environmental Education - 6oo participants; 4 conferences; 5 exhibitions; 12 events; 3 competitions.

5. Youth for the Environment (orig. Młodzi dla środowiska) - this is the latest completed ecological project under the leadership of the Catholic Youth Association (Project: Młodzi dla środowiska 2017-2019). The decision to undertake the implementation of this project was influenced, among others, by the results of studies on adult Poles. Environmental pollution in Poland results not only from infrastructure problems, but also from insufficient ecological awareness and non-ecological behaviour of Poles, as shown by the results of Research on the awareness and ecological behaviour of Polish residents carried out by the Ministry of the Environment. Research shows that the majority $(56 \%)$ of Poles do not think about whether their daily activities have an impact on the environment, and $88 \%$ of respondents do not participate in environmental campaigns. The survey of the ecological awareness of Polish residents also shows that for $77 \%$ of 
respondents, the main source of information about the environment is television. The number of people using the internet is also growing - over $60 \%$ of respondents regularly use the internet, which is why online campaigns, portals and thematic platforms are gaining importance. The activities carried out under the project raised the level of ecological education, helped in shaping proper social attitudes in relation to the environment and its protection, ensured the emergence of sustainable networks of cooperation and exchange of information, influencing the conscious management and use of environmental resources, raised the ecological awareness of the society, including local authorities. The main goal of the project was to strengthen mechanisms to protect nature and raise the level of ecological awareness by shaping the ecological attitudes of society. The specific goals included: dissemination of knowledge and information on nature protection as well as citizens' obligations and rights in this respect, among others in Natura 2000 areas and other protected areas; comprehensive ecological education and raising the level of ecological awareness and motivating project participants to take active measures for sustainable development; raising public awareness of biodiversity and education in this area, as well as promoting the idea of ecology of the spirit and Catholic social teaching on ecology. The project included: 7-day stationary and riverside workshops in the form of kayaking trips aimed at increasing the knowledge of workshop participants in the areas of: rational energy management, waste management, water protection and water management, as well as exploitation and protection of forests; a course of Ecology and Environmental
Protection Trainers-for teachers and leaders of youth environments aimed at selecting a group of leaders and trainers of ecology and environmental protection who would join local activities for ecological education in their area; workshops for families and students fulfilling their compulsory education obligation within home education, who took part in educational trips to landscape or national parks, museums (1780 participants from Home Education from all over Poland took part in these workshops); e-mail newsletter on nature-an educational campaign conducted during the whole duration of the project, promoting the project's educational and ideological thought (sustainable development, waste management, renewable energy, water protection, forest exploitation and protection, climate change), the newsletter was sent by e-mail to approximately 4,000 subscribers; ecological competitions, whose main idea was waste segregation, renewable energy and nature of Polish rivers; events dedicated to an informational and promotional campaign; an integrated digital ecological education platform-www.mlodzidlasrodowiska.pl-is a combination of an informational and promotional platform with an educational platform based on the e-learning formula. The platform is designed to provide education and promote socially and environmentally responsible behaviour building a society responsible for the environment and its resources, shaping appropriate and conscious attitudes related to the protection and rational use of environmental resources such as air, water, animated nature and minerals. The platform also allows to distribute information on climate change and the impact of our daily activities on that change. Project activities were summarized by a nationwide Conference 
"Naturally ... Poland" (orig. Naturalnie... Polska), which took place in December 2018 in Drohiczyn. The two-day meeting was attended by project participants, experts, scientists, representatives of local governments and the local community as well as ecological organizations. The nationwide coverage allowed to reach almost 150 thousand people, which means that through the project activities as large a number of people raised the level of their environmental awareness.

Projects implemented as part of the Catholic Youth Association highlight the need to take action in response to the current environmental problems. The presented activities certainly do not exhaust all possibilities and remain only an educational attempt of a Catholic nationwide organization to leave a trace in the minds of the young generation.

The currently implemented project called Youth Environment (orig. Środowisko Młodzieży) initiated by the Foundation for Youth (FDM), established by the Catholic Youth Association, adopted as its motto the goal to shape the youth environment. The training program based on Pope Francis' encyclical Laudato si', conveys a message which inspires young people to undertake their apostolic activity also in the sphere of ecology: (Project: Środowisko Młodzieży 2018)

- We have all we need because the Creator has given us everything. Our internal barriers resulting from the disturbed relationship with the Creator and creatures require our decision to overcome them and then develop habits that will permanently change and shape the attitudes of young people. This process, called formation, is what the whole society needs today. Formation

- $\quad$ Either you will shape the environment or the environment will shape you. Setting specific tasks of sharing experience can become an effective tool to counteract ecological problems in which only a person communicated with God can properly communicate in society. Communication

- Building bridges and searching for specific system solutions to reverse the processes of environmental degradation, appears as an apostolic task that the young generation should undertake out of concern for our common home.

\section{Bibliography}

Dołęga J., 2002a, Sozologia i ekofilozofia w naukach ekologicznych (Sozology and Ecophilosophy in Ecological Sciences), Ateneum Kapłańskie, Vol. 138, No. 2, 238-250.

Dołęga J., 2002b, Ekologiczna otwartość, (Ecological Openness), Ateneum Kapłańskie, Vol. 138, No. 2, 236-238.

John Paul, 1991, Encyclical Centesimus annus (Vatican, 1.05. 1991); available online: <w2. vatican.va/content/john-paul-ii/en/encyclicals/ documents/hf_jp-ii_enc_01051991_centesimusannus.html>, accessed: 19.06.2019.

John Paul II, 1989, Message for The Celebration of The World Day of Peace "Peace with God The Creator, Peace with All of Creation" (Vatican, 1.01.1990); available online: <w2.vatican.va/content/johnpaul-ii/en/messages/peace/documents/hf_jp-ii_ mes_19891208_xxiii-world-day-for-peace.html>, accessed: 19.06.2019.

Lubowicki A., 2014, Młodość w stużbie Ewangelii. Misja formacyjna Katolickiego Stowarzyszenia Młodziezy w Polsce (Youth in the Service of the Gospel. Formation Mission of the Catholic Youth Association in Poland), Teologia Pastoralna na UKSW, Warszawa.

Passicos J., 1992, Od mandatu do misji spetnianej „w imieniu Kościoła” (From a Mandate to a Mission Fulfilled "on behalf of the Church"), in: Wycisk F., Wawrzkowicz S. (eds), "Biblioteka apostolstwa ludzi świeckich - Laikat w Kościele katolickim”, Pallottinum, Warszawa, 72-87.

Project: Bug rzeka życia..., 2007-2009, project documentation submitted by KSM to the National Fund for Environmental Protection and Water Management, quarterly and final reports for 
2007-2009 remain in the archives of the Catholic Youth Association of the Drohiczyn Diocese.

Project: Elektro Odpowiedzialni, 2011-2012, project documentation submitted by KSM to the National Fund for Environmental Protection and Water Management, quarterly and final reports for 20112012 remain in the archives of the Catholic Youth Association of the Drohiczyn Diocese.

Project: Kajakowy Patrol św. Franciszka, 2009-2013, project documentation submitted by KSM to the National Fund for Environmental Protection and Water Management, quarterly and final reports for 2009-2013 remain in the archives of the Catholic Youth Association of the Drohiczyn Diocese.

Project: Młodzi dla Środowiska, 2017-2019, project documentation submitted by KSM to the National Fund for Environmental Protection and Water Management, quarterly and final reports for
2017-2019 remain in the archives of the Catholic Youth Association of the Drohiczyn Diocese.

Project: Młodzi Tej Ziemi, 2009-2010, project documentation submitted by KSM to the National Fund for Environmental Protection and Water Management, quarterly and final reports for 20092010 remain in the archives of the Catholic Youth Association of the Drohiczyn Diocese.

Project: Środowisko Młodzieży, 2018, project documentation submitted by KSM to the National Fund for Environmental Protection and Water Management in 2018. Document available in the office of the Foundation for Youth (FDM).

Statut Katolickiego Stowarzyszenia Młodzieży (Statute of the Catholic Youth Association), 1993, Warszawa-Kraków; available online: <http:// poznan.ksm.org.pl/upload/Statut-KSM.pdf $>$, accessed: 19.06.2019.

\section{Młode pokolenie katolików wobec problemów ekologicznych na przykładzie inicjatyw Katolickiego Stowarzyszenia Młodzieży}

\section{Streszczenie}

Katolickie Stowarzyszenie Młodzieży (KSM) działa w ramach 41 diecezji Kościoła rzymsko-katolickiego w Polsce i wg danych z roku 2019 liczy ok. 20000 członków zrzeczonych w 0k. 1000 oddziałów parafialnych i kół środowiskowych. Wśród licznych aktywności podejmowanych przez KSM jest działalność na rzecz ochrony stworzenia. Niniejsze opracowanie przedstawia kilka najważniejszych projektów ekologicznych realizowanych przez KSM: 1. Bug, rzeka życia edukacja dla młodzieży, młodzież dla ekorozwoju; 2. Młodzi Tej Ziemi; 3. Elektro Odpowiedzialni; 4. Kajakowy Patrol św. Franciszka; 5. Młodzi dla Środowiska; 6. Środowisko Młodzieży.

\section{Słowa kluczowe}

Katolickie Stowarzyszenie Młodzieży, chrześcijaństwo, ekologia

\section{Nota 0 autorze}

Ks. AndRZEJ LUBOWICKI - doktor teologii, w roku 2017 Konferencja Episkopatu Polski mianowała go Generalnym Asystentem Katolickiego Stowarzyszenia Młodzieży, z którym jest od lat związany. Jest on pomysłodawcą i współrealizatorem wielu projektów społecznych i ekologicznych o zasięgu diecezjalnym i ogólnopolskim.

\section{Author's note}

Fr. ANDRZEJ LUBOWICKI - theology doctor, in 2017 he was appointed by the Polish Episcopal Conference the General Assistant of the Catholic Youth Association with which he has been associated for years; initiator and co-implementer of numerous social and ecological projects of diocesan and national coverage. 